\title{
Environmental Damage Caused By The Activities Of Multi National Oil Giants In The Niger Delta Region Of Nigeria
}

\author{
${ }^{1}$ Michael Baghebo, Ph.D , ${ }^{2}$ Ubi Peter Samuel Ph.D, ${ }^{3}$ Eucharia N. Nwagbara \\ Ph.D \\ ${ }^{1}$ Department of Economics, Niger Delta University, Wilberforce Island. Bayelsa State, Nigeria. \\ ${ }^{2}$ Department of Economic, University of Calaber Nigeria. \\ ${ }^{3}$ Department of Sociology University of Calabar, Nigeria Correspondent Author: Michael Baghebo, Ph.D \\ P.O Box 1147 Yenagoa, Bayelsa State, Nigeria.
}

\begin{abstract}
This paper investigates the impact of oil and gas exploration on the host communities of the Niger Delta Region of Nigeria. It is pertinent to note that while the people of the Niger Delta Region may have benefited from oil and gas exploration, the adverse economic, environmental, health, social, urbanization impacts of the operations outweigh the benefits. Among the negative impacts are emergence of new diseases, change in water quality, a reduction in the quality of mangroves, infertility of farm land, collapse of fisheries and shift in regional climate. However, despite the negative impacts, majority of the residents would still prefer that the oil companies change the way they conduct business rather than close oil and gas exploration in the region.

Nigeria flares 17.2 billion $\mathrm{m}^{3}$ of natural gas per year in the Niger Delta. The gas flared expends huge amounts of energy and causes environmental degradation and diseases.
\end{abstract}

\section{Introduction}

The importance of the environment to man existence cannot be quantified. While environment has placed limitation on human activities, people have also changed the environment to suit their needs. Human have tried to make the environment more productive. In the past, this was done in peace male fashion but now people have an unprecedented level of scientific and technological power at their finger tip.

The past quarter of $20^{\text {th }}$ Century, there has been a global call for better environmental quality most especially after the Stockholm conference in Sweden June, 1972. The essence of the conference was to appeal to the world that the preservation and enhancement of the quality of the environment is an imperative if man is to continue in existence. In this regard, the conference acknowledges that man possesses the power to transform his environment and calls caution in the global level of water, air and land pollution.

Nigeria, the most populous country in Africa, is indisputably one of the most richly endowed countries on the continent. It boast of immense human and material resources, which provides opportunity for national development. Undoubtedly, Nigeria is a mono-cultural economy that depends mainly on oil. It is oil wealth that sustains the Nigerian economy ever since the commodity displaced agricultural resources as the mainstay of the nation's economy in the 1970's. Oil is produced in the Niger Delta, located in the southern part of the country. A delta in simple parlance describes an area with rivers, rivulets and creeks, which empty themselves into the sea. The Niger Delta of Nigeria is among the richest deltas in the world. Other deltas are either famous for crude oil and natural gas (Aazon in Brazil, Orinoco in Venezuela, Mississippi in the U.S.A, Mahakarn in Indonesia) or grow mainly rice e.g. Indus in Pakistan, Ganges in Bangladesh, Mekong in Vietnam). The Niger Delta which derives its name from the River Niger, is one of the world largest wetlands and Africans largest Delta covering some $70,000 \mathrm{~km}^{2}$ formed by the accumulation of sedimentary deposits, transported by the Niger and Benue Rivers . The Niger Delta is the centre of oil and gas production in Nigeria, accounting for about $80 \%$ of total Government Revenue, 95\% of Foreign Exchange and over 80\% of National Wealth.

The oil industry in the Niger Delta is dominated by multinational corporations such as Chevron, Texaco, Exxon-Mobil, Total, Agip, SPDC, ELF and the Nigerian National Petroleum Corporation (NNPC). Presently there are over 600 oil fields, 5,248 onshore and offshore Oil Wells, 10 Export Terminals, 275 Flow stations, 4 Refineries and a Liquefied National Gas Project. As at 2007, Statistics produced in the Niger Delta, which amounts to a staggering National Revenue of 29.8 trillion naira (TELL, February 18, 2008:28). The recent Niger Delta Development Bill defines the Niger Delta to include the South-South geo-political zone, comprising Edo, Delta, Bayelsa, Rivers Akwa Ibom and Cross River states, and neighbouring oil producing parts of Ondo, Abia and Imo States. 
Notwithstanding the abundant wealth that the region parades, the people live in a state of chronic squalor and abject poverty. Oil seemed to be a curse to the people of the Niger Delta. Its exploration and exploitation since 1956 has set in political, ecological and socio-logical conditions that generate abject poverty, misery and backwardness in the region. Prior to discovery and exploration of oil and gas resources in the region, the primary occupation of the people was fishing and farming. It is however sad to note that, oil exploration and exploitation has destroyed the subsistence economy of the people. Testimonies from various quarters lend credence to the claim that environmental degradation occasioned by oil spillages has made life extremely difficult for the local people. This study tries to highlight the damages cause by the exploration and exploitation of oil in the region by the Multinational oil giants.

The population of the region stands in the neighbourhood of 29 million, consisting of over forty unique ethnic groups, with 250 different languages and dialects. Among the ethnic group include Andoni, Degema, Edo, Efik, Egbema, Ekpeye, Engene, Etche, Ibibio, Ibo, Ijaw, Ikala, Ikwere, Ilaje, Itsekiri, Isoko, Kalagbari, Ogoni, Okirika, and Urhobo. The main occupation of the people of the Niger Delta are farming and fishing. Given the quantity of resources (oil and gas) endowed, the region has become the bread-winner of the country.

In Nigeria, the Niger Delta Region is the main source of the oil production, accounted for the bulk of the country's revenue. Before oil was discovered in the region, the people of the Niger Delta lived on the exploitation of natural resources of their land, water and forest. Since the inception of oil production in the region, the area has suffered various devastating impacts resulting from the activities of the multi-national oil companies. No part of the world feels the negative impacts of oil and gas exploration more than the people of the Niger Delta Region of Nigeria.

Since the inception of oil exploitation in the region, the Niger Delta has experienced unprecedented environmental degradation. Inhabitants of the area are confronted with serious environmental health risks. The cities are overcrowded due to steady migration of people from rural area and surrounding states in search of jobs to sustain their families. There is no doubt that the presence of the oil and gas industry provides some opportunities for the people of the Niger Delta and surrounding states. However, those benefits pale in comparison to the costs these communities incur as a result of these human activities.

Farm land, forest, and water no longer yield adequate produce to sustain the people. The Niger Delta region is inflicted with massive poverty emanating from environmental degradation due to oil and gas exploration in the region by oil companies. Besides economic impacts, the Niger Delta is characterized by increasing cases of vandalism and kidnapping of oil workers. The region has become quite dangerous, adding to the massive poverty, environmental degradation, and worst of all, neglect. The activities of the oil and gas industry in the region have created situations leading to social disorder and violence between communities

The rest of the work is organized as follows: section two is literature review, discussion of Environmental damages caused by multinational oil companies in the Niger Delta is contain in section three, section four contain policy recommendations, while section five concludes the work.

\section{Literature Review}

Oil industry has created situations for social dislocation and communal violence in the oil rich Niger Delta Region. While the direct effect of oil and gas production are borne by the Niger Delta states, other communities also suffer from direct impact of oil and gas industry activities. According to Osouka (2007), exploration of oil and gas presents multiple forms of environmental degradation. Oil pollution kills fish, their food sources and fish larvae, and damages the ability of fish to reproduce, causing both immediate damage and long-term harm to fish stocks. Oil pollution also damages fishing equipment and pollutes drinking water in wells. Oil spills and waste dumping have also seriously damage agricultural land. Long-term effects include damage to soil fertility and agricultural productivity, which in some cases can last for decades. Economically, the costs of those products become exorbitant given the law of supply and demand.

The negative impact of environmental consequences of the oil industry activities are mainly localized within the host communities. However, some of the effects have trans-boundary implications. Gas flaring is a contributing factor to global warming. The Niger Delta Region and the neighbouring states suffer environmental degradation, which deprives them of means of livelihood as well as other economic and social factors as part of negative consequences of oil exploitation. The environmental challenges faced by the country at large and the people of the Niger Delta Region in particular demand attention. The level of environmental degradation caused by the oil and gas exploration in the area has escalated beyond imagination. Though, the region is also experiencing economic expansion, however, the negative environmental impact caused by human activities like oil and gas exploration underscore the need for full accountability in order to understand the costs to the host communities.

In 1999, a tragedy befell the citizens of Erovie, a community in Niger Delta who were poisoned by toxic waste from Shell Oil's Operations. Local residents began to experience health problems soon after Shell Oil Company injected a million litres of a waste into an abandoned oil well in Erovie. Many who consumed 
crops or drank water from swamps in the area complained of vomiting, dizziness, stomach ache and cough. Within two months 93 people had died from this mysterious illness. Independent tests by two Nigerian universities and three other laboratories, conducted in the year after the health problems emerged, indicated that the substance was toxic. All the tests confirmed poisonous concentrations of lead, zinc and mercury in the dumped substance. In 2002, Waste disposal and pollution by the Warri Refinery and Petrochemicals Company (WRPC) have spoiled fishing and reportedly has caused a number of deaths among the Itsekiri people.

\section{Environmental Damages Caused By Multinational Oil Giants In The Niger Delta}

In the Niger Delta, the environment is confronted with environmental problems caused by oil and nonoil activities. The non-oil related environmental problems include, coastal/river bank erosion, flooding, spread of exotic species, agricultural land degradation, depletion of aquatic life, inadequate sanitary and waste management.

The oil related environmental problems are oil spills, gas flaring, dredging of canals etc. Ever since the discovery of oil in Oloibiri in 1956, the Niger Delta environment has known no respite. As a result of equipment failure and sabotage, oil spills have become endemic and devastating in the Niger Delta.

In 2001, the Western Operations of the Shell Petroleum development Company (SPDC) recorded a total of 115 incidents of oil spills in which 5,187.14 barrels of the spilt oil, representing 14.2 percent were recovered (SPDC Western Operations, Environmental Department, August 2002). Since 1989, the SPDC has recorded an average of 221 spills per year in its operations area, involving a total of 7,350 barrels annually (SPDC Nigeria Briefs, May 1995:3). Other oil multinational also spill oil into the Niger Delta environment. For example, in January 1998, 40,000 of light crude oil were spilled by Mobil in Eket.

Furthermore, oil spills statistics shows that a total of 2,796 oil spill incidences were recorded between 1976 and 1990, leading to the spilling of 2,105,393 barrels of oil. Three million barrels of oil were lost to 6,817 oil spill incidents between 1976 and 2001; over 70 percent of the spilt oil was not recovered. The World Bank has also noted in 1995 that about $2,300 \mathrm{~m}^{3}$ of oil was spilt in 300 separate incidences in old Rivers (which include Bayelsa State) and Delta States. The destruction of farmlands, fishponds and rivers had adversely affected the economic life of the people.

Table 1. Summary of Some Oil Spills in the Niger Delta

\begin{tabular}{|l|l|l|l|}
\hline Episode & Year & State & $\begin{array}{l}\text { Quantity of spilt in } \\
\text { barrels }\end{array}$ \\
\hline Forcados terminal oil spills & 1979 & Delta & 570,000 \\
\hline Funiwa No.5 well blow out & 1980 & Rivers & 400,000 \\
\hline Oyakama oil spillage & 1980 & Rivers & 10,000 \\
\hline $\begin{array}{l}\text { System 2c Warri - Kaduna Pipeline rupture } \\
\text { at Abudu }\end{array}$ & 1982 & Edo & 18,000 \\
\hline Sohika oil spill & 1983 & Rivers & 10,000 \\
\hline Idoho oil spill & 1983 & Akwa-Ibom & 40,000 \\
\hline Jones creek oil spill & 1998 & Delta & 21,000 \\
\hline Jesse oil spill & 1998 & Delta & 10,000 \\
\hline Etiama oil spill & 2000 & Bayelsa & 11,000 \\
\hline Ughelli oil spill & 2005 & Delta & 10,000 \\
\hline Bongo oil spill & 2011 & & 40,000 \\
\hline
\end{tabular}

Source: United Nations Development Programme (UNDP), Niger Delta Human Development Report, Abuja, Nigeria, 2006, P:184, and www.africaliberty.org

Table 1 which is a summary of some Oil Spills in the Niger Delta captures a disturbing scenario of environmental devastation in the Niger Delta. The oil companies continuously blame many of the oil spills on sabotage. For example, though the Shell Petroleum Development Company (SPDC) reported 1,137 cases of sabotage, involving 17,644 barrels of spilt oil in 2000. The Department of Petroleum Resources (DPR) affirms that the incidence is traceable to equipment failure.

The multinationals operating in the region did not conform to international standard. For example, the oil companies adopt the "Open pipe flare" method to flare gas in the area. This method is obsolete, and is not used by these same companies in the developed countries. The "Open pipe flare" method degrades the environment more than accepted types, such as the "ground open flare" with Sand Banks. Most of the black smoke associated with the open pipe type contains element derived from the products of incomplete combustion, including soot and various sizes of carbon particles which are both hazardous'. 
The twin evils of oil spills and gas flaring, in addition to seismographic and construction activities of the oil companies have undermined the local economies of Oil Producing Communities, leading to occupational disorientation and the exacerbation of poverty.

The following are some adverse impact of oil exploration and exploitation in the region. Soil erosion Erosion due to construction activities, Loss of vegetation and biodiversity, fauna and flora due to construction of access tracks and drill sites, extensive vegetation loss due to fire; facilitation of encroachment in forests. Water Contamination of surface and ground water with oil, drilling mud and effluents: disruption of water courses or drainage.

Landscape - Visual intrusion of drilling rigs; night lighting; flaring of gas.

Air - smoke from gas flare; offensive odour.

Wildlife - poacher access; disturbance of wildlife; pollution of water sources. Deforestation and desertification: due to indiscriminate felling of trees for site shelter and other use by worker of multinational oil producing companies. Communities - Disturbance of previously remote communities: pollution or loss of vital natural resources for medicinal and other purpose.

Culture - Damage to archaeological sites that are of historical or cultural importance. It is clear from the forgoing, that the oil industry impact negatively on the economies of the oil Producing communities. Farming and fishing which is the mainstay of the local economies are castrated. For example, total recovery for an oil spill impacted land takes as long as 10 to 15 years. This is made worse by delay in cleanup due to insensitivity on the part of the operating company, bureaucratic bottlenecks or disagreement between communities and oil companies.

This disagreement favours the multinational oil companies which looses nothing while they stand off lasts. There are examples of spills where clean up takes months or years. In Epubu community, a spill that occurred in December 1998 was not clean until about a year. Similarly, a spill that occurred at Aleibiri in March 1997 was not attended to for 6 months, until youths of the community staged protest. Also, a spill that occurred in October 1995 at Akenfa and Ogboloma communities was not cleaned until December of that same year (Ibaba, 2005). The cases are indeed numerous. The effect is the worsening of ecological devastation. Gas flaring destroys the buffer covering of the atmosphere that guides against ultra-violet ray of sun (The Ozone layer).

The impact of environmental damage in the region cannot be quantified. Many have argued that the plethora of environmental damages caused by oil exploration and exploitation have ignited the various conflicts in the region all this while. It is undisputable that oil spill impacted lands and waters to experience the declining productivity in farming and fishing. The immediate effect is the destruction of crops and marine life in the long run: It reduces the nutrient value of the soil and makes the Water contaminated. Related to oil spills is gas flaring, which is as old as the oil industry in Nigeria. Nigeria flares about 75 percent of gas it produces more than any other country in the World. Available information indicates that a total of 5.0 Trillion cubic feet of associated gas was flared in Nigeria, between 1958 and 1999. This represents 85 percent of the 5.7 Trillion cubic feet that was produced within the period. Gas flaring is associated with many devastating health ailments that affect human beings. Apart from this, the heat it generate kills vegetation around the flare area, destroys mangroves, swamps and salt marsh, suppresses the growth and the flowering of some plants, induces soil degradation and diminishes agricultural production.

\section{Policy Recommendation}

The starting point for a meaningful solution to Niger Delta problem must be the environment. The following policy recommendation that can fast track development and better environmental condition in the region is advocated:

1. The statutory stipulation for environmental impact assessment (EIA), both for oil companies and industrial organizations, must be strictly adhered to.

2. An alternative development agenda that is people-centred must be instituted.

3. Employment opportunities must be mapped out for indigenes displaced from their farmstead.

4. Soil samples must be taken at regular interval to check the level of toxicity, and correspondingly, a comprehensive programme of remediation must be instituted.

5. Aquatic life must be similarly monitored.

6. A strict deadline for the stoppage of gas flaring must be agreed on, and contingency plan must be put in place to carter for those who are adversely affected by gas flaring.

7. Oil spillage must be monitored and reported promptly, and an effective remediation programme must be put in place.

8. Oil companies must strive towards the modernization of infrastructures and equipment, replacement of old and corroded pipes to prevent further oil spillage.

9. Oil companies should always implement the provisions of the memorandum of understanding (MOU) signed with the communities; 
10. Trans-national oil companies should reserve a percentage of job openings for qualified and employable youths in their host communities.

11. Governments and the various oil companies should adopt a deliberate policy of village, community and indigenes ownership of a fraction of oil companies operating in their area through allocation of shares and profit sharing;

12. Oil companies should install air pollution abatement devices to ensure that only clean air is discharged into the environment.

\section{Conclusion}

This study reveals that the causes of the environmental damages in the Niger Delta region are mainly as a result of oil and gas exploration and exploitation. The insensitivity of the multinational companies towards the Niger Delta environment had led to severe damages and in some cases un-repairable damages to the Niger Delta environment. Oil exploration and exploitation had made a God's blessed land to appear God forsaken. This paper recommends drastic and holistic implementation of the above highlighted policies for sustainable environment.

\section{Acknowledgement}

I am grateful to Profs: Gesiye Salo Angaye, Akpan H. Ekpo, Wilfred A. Ndongko and Nyong M.O. for their excellent intellectual and moral support.

\section{Referencces:}

[1] Afinotan L.A and Ojakorotu (2009) The Niger Delta crisis: issues, challenges and prospects. African Journal of Political Science and international relations Vol. 3 (5), pp. 191-198, May.

[2] C. O. Opukri \& Ibaba S. Ibaba(2005). Sabotage induced Oil Spillages and Human Right. Journal of Sustainable Development in Africa Volume 12, No.2: 13

[3] NDDC (Niger Delta Development Commission) http://www.nddconline

[4] Osuoka (2007) Multiple forms of environmental degradation by exploration of Oil and Gas.Retrieved14,November2012.htt//wwwearthlife.org.za/worldpress/wp-content/upload/2009/02/sense-29.pdf

[5] UNDP (2006)Niger Delta Human Development Report, Abuja Nigeria. Page 184 www.africaliberty.org

[6] TELL Newspaper, February 18,2008:28 